\title{
Nutrient resorption strategies of three oak tree species in response to interannual climate variability
}

\author{
Baoming Du', Huawei Ji', Shirong Liư ${ }^{1}$, Hongzhang Kang ${ }^{3}$, Shan Yin ${ }^{1,4,5^{*}}$ and Chunjiang $\mathrm{Liu}^{1,4,5^{*}}$ (D)
}

\begin{abstract}
Background: Nutrient resorption is critical for plants toward balancing their nutritional requirements and adapting to environmental variabilities, which further impacts litter quality and nutrient cycling. However, the interannual variability of nutrient resorption under climate change remains unclear.

Methods: We investigated the five-year nutrient resorption efficiencies (NuRE, \%) of 14 elements in three deciduous oak tree species (Quercus aliena var. acuteserrata, Q. glandulifera, and Q. variabilis) in a warm-temperate forest of Central China and assessed their relationships with interannual climate and soil factors.

Results: Nutrient resorption did not differ between species but varied significantly between different years. For each year, N, P, S, K, C, Mg, and Zn were preferentially resorbed in all of the oak species in contrast to $\mathrm{Ca}, \mathrm{Na}, \mathrm{Mn}$, $\mathrm{Ba}, \mathrm{Al}, \mathrm{Fe}, \mathrm{Cu}$, which were to some extent discriminated. Among the 14 elements, the NuRE of C, N, P, S, Ca, and Mg was more sensitive to interannual climate variations in the three oak species. The carbon resorption efficiency was significantly increased during the driest year of the study (2014); $N$ resorption efficiency was reduced with temperature; whereas $\mathrm{N}$ and $\mathrm{P}$ resorption efficiency initially decreased and then increased with precipitation. Moreover, the elements with higher NuREs typically had lower coefficient of variation (CV) in all three oak species.

Conclusions: Different oak species exhibited analogous nutrient conservation strategies in response to annual climate variabilities, and interannual climate variations strongly impacted plant nutrient resorption. Deciduous plants may establish a tradeoff mechanism to rebalance somatic nutrients for regrowth at the end of the growing season.
\end{abstract}

Keywords: Nutrient resorption, Tradeoff mechanism, Climate change, Quercus spp., Temperate forests

\section{Background}

Plants obtain the nutrients they require, on one hand, through soil nutrient cycling, which includes inputs from litter decomposition, biological fixation, atmospheric deposition, weathering, removal by root uptake, and leaching losses (Pallardy 2010; Cronan 2017), and on the other hand through the reallocation of nutrients to different structures (Killingbeck 2004; Marschner and Marschner 2012). Nutrient resorption is a process through which plants reallocate nutrients from senescing structures to

\footnotetext{
* Correspondence: yinshan@sjtu.edu.cn; chjliu@sjtu.edu.cn

'School of Agriculture and Biology, Shanghai Jiao Tong University, 200240 Shanghai, China

Full list of author information is available at the end of the article
}

storage and/or developing tissues, which contributes to a reduction in their dependence on nutrient uptake (Aerts and Chapin 1999; Killingbeck 2004; Brant and Chen 2015). Nutrient resorption can assist plants with adapting to environmental variabilities (May and Killingbeck 1992; Killingbeck 1993; Prieto and Querejeta 2020), which can further affect plant reproduction, litter decomposition, and ecosystem nutrient cycling through altering nutrient storage and litter quality (Attiwill and Adams 1993; Aerts 1996; Xu et al. 2020). Therefore, the study of nutrient resorption under climate change has gained increasing attention in recent years (Fujita et al. 2014; Yan et al. 2016; Drenovsky et al. 2019).

\section{Springer Open}

(c) The Author(s). 2021 Open Access This article is licensed under a Creative Commons Attribution 4.0 International License, which permits use, sharing, adaptation, distribution and reproduction in any medium or format, as long as you give appropriate credit to the original author(s) and the source, provide a link to the Creative Commons licence, and indicate if changes were made. The images or other third party material in this article are included in the article's Creative Commons licence, unless indicated otherwise in a credit line to the material. If material is not included in the article's Creative Commons licence and your intended use is not permitted by statutory regulation or exceeds the permitted use, you will need to obtain permission directly from the copyright holder. To view a copy of this licence, visit http://creativecommons.org/licenses/by/4.0/. 
Nutrient resorption varies substantially with temperature and precipitation along large geographical gradients (Kobe et al. 2005; Yuan and Chen 2009; Reed et al. 2012; Vergutz et al. 2012; Du et al. 2017; Tong et al. 2021). Climate change issues including global warming, extreme drought, and $\mathrm{N}$ deposition also influence nutrient resorption (Suseela et al. 2015; Zheng et al. 2018; Huang et al. 2018; Prieto and Querejeta 2020; Lü et al. 2021). For instance, climatic warming may reduce nutrient resorption (Suseela et al. 2015), while drought can advance leaf senescence, which increases (Lobo-do-Vale et al. 2019) or reduces (Zhao et al. 2020) resorption. Aside from climatic factors, nutrient resorption is also determined through the availability of soil nutrients, plant nutrient status, and functional groups (Chapin and Moilanen 1991; Wright and Westoby 2003; Liu et al. 2014; Bahamonde et al. 2019; Gerdol et al. 2019; Xu et al. 2020), as well as source-sink relations (Killingbeck 2004), and the mobility of nutrients in the phloem (Bukovac and Wittwer 1957; Hill 1980). Since most species are unlikely to migrate quickly enough to keep pace with environmental changes (IPCC 2014), the capacity to adapt to variations in localized environments might assist them with surviving under the altered climatic environments that are anticipated in the near future (Jump and Peñuelas 2005; Prieto and Querejeta 2020). However, it is largely unknown how local plants might respond to disparities in environmental factors that are driven by interannual climate variations, which is critical to elucidate the physiological and evolutionary adaptation of plants under climate change.

The nutrient resorption levels of plants are associated with their constituent elements (Liu et al. 2014). Generally, N, P, S, and $\mathrm{K}$ are preferentially withdrawn from senescing leaves and exhibit high resorption, while $\mathrm{Ca}$, $\mathrm{Mg}, \mathrm{Al}$, and $\mathrm{Fe}$ are accreted in senesced leaves, thus, showing low or negative resorption (Killingbeck 1993; Liu et al. 2014; Estiarte and Peñuelas 2015; Du et al. 2017; Prieto and Querejeta 2020). Various elements are often distributed in a coordinated pattern during the nutrient resorption process in a tradeoff manner (Killingbeck 1993, 2004), i.e. some elements are taken up preferentially $(\mathrm{NuRE} \geq 0)$ and others are discriminated $(\mathrm{NuRE}<0)$ (Du et al. 2017). Further, to adapt to environmental changes, plants have also evolved a homeostasis mechanism that is based on the stability of the limiting elements hypothesis, i.e. with higher elemental concentrations and lower variability (low coefficient of variation) (Han et al. 2011). However, less is known about how different nutrients interact during the resorption process. Moreover, plants growing at the same sites may exhibit parallel or convergent adaptations in terms of functional traits, physiology, and genetics (Aspinwall et al. 2016; Yeaman et al. 2016; Bauters et al. 2017; Bahamonde et al. 2019). Whether different plants also exhibit analogous responses in nutrient resorption remains unclear. These findings will assist ecologists with optimizing their biogeochemical models, while improving their understanding of nutrient cycling.

The genus Quercus is widely distributed in temperate forests of the Northern Hemisphere and provides important ecological and economic roles (Aldrich and Cavender-Bares 2011). In our study area, three Quercus species emerged to dominate an area. Previous studies have focused primarily on the impacts of warming and drought on soil carbon dynamics (Liu et al. 2017), spatiotemporal variations in plant stoichiometry, and water use efficiencies in different oak forests ( Du et al. 2017, 2021), yet, less is known about the effects of annual climatic variations on nutrient resorption. For this study, we investigated the interannual variations in multiple element stoichiometry and resorption for three deciduous oak species over five years. Our objectives were to examine the nutritional responses of different plants to climatic differences driven by interannual variability, and to assess the regulation patterns and driving factors of nutrient resorption based on climate change and multiple additional elements. To achieve our objectives, we measured the NuRE variations of seven macroelements (C, N, P, S, K, Ca, and Mg), four microelements (Fe, Mn, $\mathrm{Zn}$, and $\mathrm{Cu}$ ), and three trace elements $(\mathrm{Na}, \mathrm{Al}$, and $\mathrm{Ba})$ (CRE referenced Vergutz et al. 2012). We evaluated the effects of interannual temperature, precipitation, as well as green leaf concentration and soil nutrient status, on the nutrient resorption of multiple elements.

\section{Materials and methods}

\section{Study area}

This study was conducted from 2013 to 2016, and 2018 at the Forest Ecological Research Station of the Baotianman Natural Reserve $\left(111^{\circ} 47^{\prime}-112^{\circ} 04^{\prime}\right.$ E, $33^{\circ} 20^{\prime}-33^{\circ} 36^{\prime}$ $\mathrm{N}, 500$ to $1,845 \mathrm{~m}$ a.s.l) in Henan Province, Central China. The missing study in 2017 was caused by accidental damage to the sampling equipment. This area belongs to a temperate-subtropical ecotone zone with mean annual precipitation of $936 \mathrm{~mm}$, and air temperature of $12.4{ }^{\circ} \mathrm{C}$ over the past thirty years (from 1981 to 2010) (http://climateap.net/). With the main soil type comprised of haplic luvisol (Liu et al. 2017), the forest primarily consists of deciduous oak, including $Q$. aliena var. acuteserrata, Q. glandulifera, and Q. variabilis, in addition to several minor components of other deciduous woodland species and shrubs.

\section{Soil and leaf sampling}

Three study sites were selected, where each site represented a stand of a subject tree species. For each site, three $20 \mathrm{~m} \times 20 \mathrm{~m}$ plots were demarcated and the latitude, longitude, and altitude were recorded with a global positioning system (Thales Navigation, Santa Barbara, 
Table 1 Site and vegetation conditions of the three Quercus stands under study at the Baotianman Natural Reserve of Central China

\begin{tabular}{|c|c|c|c|c|c|}
\hline Stands & Latitude $\left({ }^{\circ}\right)$ & Longitude $\left({ }^{\circ}\right)$ & Altitude (m) & Tree height (m) & $\mathrm{DBH}(\mathrm{cm})$ \\
\hline Q. aliena var. acuteserrata & 33.497 & 111.933 & 1423 & $19.1 \pm 1.7$ & $31.3 \pm 4.8$ \\
\hline Q. glandulifera & 33.496 & 111.930 & 1416 & $19.4 \pm 1.6$ & $28.1 \pm 0.7$ \\
\hline Q. variabilis & 33.494 & 111.926 & 1320 & $21.7 \pm 0.5$ & $34.1 \pm 5.8$ \\
\hline
\end{tabular}

Diameter at breast height (DBH) of trees was measured at $1.3 \mathrm{~m}$. Tree height was estimated using an ultrasonic altimeter

CA, USA) (Table 1). Within each plot, five dominant trees were selected for the collection of leaf samples in the upper central south-facing part of crown. Two hundred leaves were collected in August (green leaves) and again in December (senesced leaves). The green and senesced leaves were obtained by cutting the upper middle branches with a retrofitted fishing rod on the ground. A total of five soil cores $(0-10 \mathrm{~cm})$ were randomly extracted using a $2-\mathrm{cm}$ diameter stainless-steel earth borer in each plot, which were combined to produce a composite sample. The soil samples were airdried, while the green leaf and senesced leaf samples both were oven dried $\left(65^{\circ} \mathrm{C}\right)$ for $72 \mathrm{~h}$. The soil and leaf samples were ground and sieved through a 60-mesh sieve $(0.25 \mathrm{~mm}$ diameter) for chemical analysis.

Nutrient resorption was expressed as the difference in the elemental concentrations between the green $\left(X_{\mathrm{gr}}\right)$ and senescent $\left(X_{\text {sen }}\right)$ leaves by dry mass.

$$
\begin{aligned}
\text { Nutrient resorption efficiency }= & \left(1-\frac{X_{\text {sen }}}{X_{\mathrm{gr}}} \text { MLCF }\right) \\
& \times 100
\end{aligned}
$$

where MLCF is the mass loss correction factor and $~ 0.784$ for deciduous broadleaved species (Vergutz et al. 2012).

\section{Chemical analyses}

The total $\mathrm{C}$ and $\mathrm{N}$ concentrations of the leaves and soil were determined using elemental analysis (Vario EL cube, Elementar, Germany) (Sun et al. 2012), whereas the total $\mathrm{P}, \mathrm{S}, \mathrm{K}, \mathrm{Na}, \mathrm{Ca}, \mathrm{Mg}, \mathrm{Al}, \mathrm{Fe}, \mathrm{Mn}, \mathrm{Zn}, \mathrm{Cu}$, and $\mathrm{Ba}$ were assessed using an inductively coupled plasma optical emission spectrometer (ICP-OES) (Iris Advantage 1000, Thermo Jarrell Ash, Franklin, MA, USA) following digestion with hydrofluoric and nitrohydrochloric acid for the soil samples, and nitric and perchloric acid for the leaf samples.

\section{Data analyses}

Soil element concentrations of the three sampled oak species sites are summarized in Table S1. Meteorological data was obtained from the Neixiang Meteorological Bureau and Baotianman Forest Ecological Research Station (Fig. 1). One-way ANOVA was conducted to test the differences in nutrient resorption between the different years. One-way repeated measures ANOVA was employed to determine whether resorption of nutrients and their interacting effects differed between species and years. Cluster analysis was run to group elements by NuRE. Subsequently, linear regressions were employed to examine the nutrient resorption correlations with MAT, MAP, and the concentrations of elements in the green leaves.

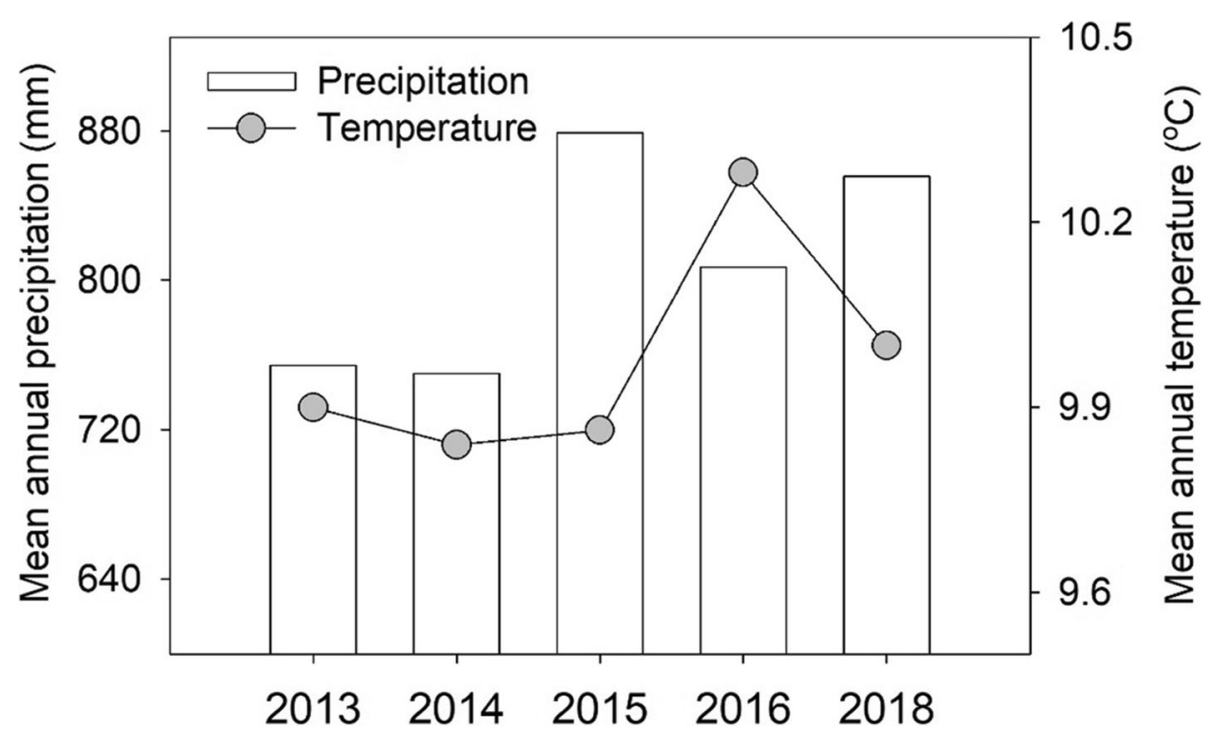

Fig. 1 Mean annual temperature and precipitation over five years in the Baotianman Mountains of Central China 
Table 2 Nutrient resorption efficiency (NuRE) (Mean \pm SE) of three oak species (Q. aliena var. acuteserrata, Q. glandulifera, and Q. variabilis) over five years

\begin{tabular}{|c|c|c|c|c|c|c|}
\hline \multirow[t]{2}{*}{ Element } & \multirow{2}{*}{$\begin{array}{l}\text { Tree } \\
\text { species }\end{array}$} & \multicolumn{5}{|l|}{ Year } \\
\hline & & 2013 & 2014 & 2015 & 2016 & 2018 \\
\hline \multirow[t]{3}{*}{ C } & 1 & $20.58 \pm 0.46 b$ & $25.02 \pm 0.22 \mathrm{a}$ & $19.19 \pm 0.30 c$ & $20.60 \pm 0.26 b$ & $21.41 \pm 0.51 b$ \\
\hline & 2 & $20.37 \pm 0.43 c$ & $24.22 \pm 0.33 a$ & $20.31 \pm 0.40 c$ & $20.42 \pm 0.08 c$ & $22.16 \pm 0.40 b$ \\
\hline & 3 & $21.94 \pm 0.91 b$ & $24.48 \pm 0.62 a$ & $20.30 \pm 0.98 b c$ & $19.83 \pm 0.04 c$ & $20.69 \pm 0.23 b c$ \\
\hline \multirow[t]{3}{*}{ N } & 1 & $68.33 \pm 0.94 a$ & $71.24 \pm 0.41 a$ & $65.17 \pm 2.88 \mathrm{a}$ & $50.27 \pm 3.61 b$ & $68.10 \pm 0.42 a$ \\
\hline & 2 & $68.61 \pm 1.29 a$ & $72.64 \pm 1.06 a$ & $67.97 \pm 1.56 a$ & $57.70 \pm 3.70 b$ & $71.77 \pm 0.70 \mathrm{a}$ \\
\hline & 3 & $65.97 \pm 1.94 b$ & $70.78 \pm 0.36 a$ & $67.16 \pm 1.13 b c$ & $62.08 \pm 1.90 c$ & $66.54 \pm 0.15 b c$ \\
\hline \multirow[t]{3}{*}{$P$} & 1 & $82.38 \pm 0.89 a$ & $84.93 \pm 1.67 a$ & $81.58 \pm 0.99 a$ & $60.86 \pm 6.50 \mathrm{~b}$ & $59.79 \pm 1.79 b$ \\
\hline & 2 & $85.44 \pm 0.67 a$ & $86.52 \pm 0.37 a$ & $84.20 \pm 0.79 a$ & $70.74 \pm 5.33 b$ & $52.79 \pm 1.34 c$ \\
\hline & 3 & $83.20 \pm 1.47 a$ & $83.75 \pm 1.57 a$ & $85.50 \pm 0.80 a$ & $77.60 \pm 0.72 b$ & $53.48 \pm 0.78 c$ \\
\hline \multirow[t]{3}{*}{ S } & 1 & $50.48 \pm 0.33 b$ & $62.06 \pm 0.96 a$ & $53.49 \pm 2.04 a b$ & $36.43 \pm 5.83 c$ & $54.27 \pm 0.33 \mathrm{ab}$ \\
\hline & 2 & $53.92 \pm 2.12 b$ & $64.62 \pm 3.01 \mathrm{a}$ & $53.90 \pm 2.00 \mathrm{~b}$ & $46.11 \pm 1.03 c$ & $48.87 \pm 0.63 \mathrm{bc}$ \\
\hline & 3 & $43.86 \pm 3.58 c$ & $64.18 \pm 2.77 a$ & $54.20 \pm 0.84 b$ & $49.75 \pm 0.96 b c$ & $45.68 \pm 0.92 c$ \\
\hline \multirow[t]{3}{*}{ K } & 1 & $70.19 \pm 1.55$ & $78.16 \pm 1.56$ & $77.34 \pm 3.18$ & $67.30 \pm 6.69$ & $77.41 \pm 2.00$ \\
\hline & 2 & $70.36 \pm 3.12$ & $76.07 \pm 3.68$ & $79.29 \pm 3.36$ & $69.19 \pm 3.99$ & $73.57 \pm 2.40$ \\
\hline & 3 & $71.62 \pm 2.37$ & $69.64 \pm 3.98$ & $70.21 \pm 1.56$ & $69.66 \pm 0.78$ & $69.19 \pm 1.16$ \\
\hline \multirow[t]{3}{*}{$\mathrm{Na}$} & 1 & $65.64 \pm 5.85 a$ & $-38.71 \pm 8.04 a b$ & $-29.03 \pm 30.22 b$ & $-45.82 \pm 61.48 a b$ & $27.41 \pm 3.47 a b$ \\
\hline & 2 & $40.45 \pm 9.05 a$ & $-45.69 \pm 13.20 c$ & $-24.60 \pm 14.36 b c$ & $12.57 \pm 34.25 \mathrm{abc}$ & $16.77 \pm 2.84 a b$ \\
\hline & 3 & $24.55 \pm 14.64 a$ & $-69.13 \pm 28.59 b$ & $13.34 \pm 10.50 a$ & $-19.10 \pm 19.81 a b$ & $24.36 \pm 3.76 a$ \\
\hline \multirow[t]{3}{*}{$\mathrm{Ca}$} & 1 & $8.11 \pm 3.60 \mathrm{a}$ & $-32.61 \pm 7.25 b$ & $-21.02 \pm 11.83 b$ & $8.79 \pm 4.95 a$ & $31.27 \pm 6.25 a$ \\
\hline & 2 & $-7.34 \pm 2.94 \mathrm{bc}$ & $-27.46 \pm 1.36 d$ & $-21.46 \pm 7.47 \mathrm{~cd}$ & $11.77 \pm 7.12 \mathrm{a}$ & $3.47 \pm 4.37 a b$ \\
\hline & 3 & $-6.35 \pm 10.41 a b$ & $-49.00 \pm 7.42 c$ & $-13.63 \pm 12.22 b$ & $18.32 \pm 1.50 a$ & $11.78 \pm 2.72 a b$ \\
\hline \multirow[t]{3}{*}{$\mathrm{Mg}$} & 1 & $32.80 \pm 5.93$ & $22.80 \pm 4.75$ & $34.55 \pm 4.27$ & $25.53 \pm 12.21$ & $45.68 \pm 2.80$ \\
\hline & 2 & $23.54 \pm 3.23 b$ & $8.81 \pm 1.19 c$ & $25.81 \pm 2.08 a$ & $34.64 \pm 5.91 a$ & $31.02 \pm 0.94 a b$ \\
\hline & 3 & $10.13 \pm 9.48 b$ & $0.28 \pm 5.94 b$ & $20.32 \pm 2.80 a b$ & $31.37 \pm 4.79 a$ & $23.76 \pm 5.07 a b$ \\
\hline \multirow[t]{3}{*}{$\mathrm{Al}$} & 1 & $-99.94 \pm 16.82 b$ & $-46.75 \pm 15.56 a b$ & $-66.32 \pm 9.95 b$ & $-101.92 \pm 27.44 b$ & $-3.58 \pm 19.97 a$ \\
\hline & 2 & $-143.88 \pm 20.34 b$ & $-39.40 \pm 30.06 a$ & $-66.90 \pm 15.83 a$ & $-5.22 \pm 3.48 a$ & $-67.89 \pm 14.43 a$ \\
\hline & 3 & $-142.46 \pm 12.66 c$ & $-58.17 \pm 16.43 a b$ & $-69.48 \pm 10.15 a$ & $-38.56 \pm 13.68 a$ & $-107.48 \pm 4.40 b$ \\
\hline \multirow[t]{3}{*}{$\mathrm{Fe}$} & 1 & $-135.86 \pm 11.40 d$ & $-14.73 \pm 8.07 a b$ & $-6.02 \pm 10.85 a$ & $-69.67 \pm 19.82 c$ & $-47.58 \pm 0.47 b c$ \\
\hline & 2 & $-140.85 \pm 8.93 c$ & $-4.94 \pm 14.99 a$ & $-7.43 \pm 6.86 a$ & $-5.02 \pm 7.24 a$ & $-89.21 \pm 10.44 b$ \\
\hline & 3 & $-112.38 \pm 14.27 c$ & $-30.15 \pm 19.08 b$ & $8.63 \pm 6.58 a$ & $29.77 \pm 20.73 a$ & $-51.29 \pm 10.28 b$ \\
\hline \multirow[t]{3}{*}{$\mathrm{Mn}$} & 1 & $28.40 \pm 3.80 a$ & $-37.56 \pm 11.70 c$ & $-14.71 \pm 8.63 b c$ & $3.28 \pm 10.61 \mathrm{ab}$ & $0.90 \pm 11.95 \mathrm{ab}$ \\
\hline & 2 & $-0.21 \pm 6.45 a$ & $-61.24 \pm 38.24 b$ & $-10.38 \pm 6.17 a b$ & $3.92 \pm 11.15 a$ & $1.07 \pm 2.09 a$ \\
\hline & 3 & $18.83 \pm 10.19 a$ & $-21.96 \pm 11.39 b$ & $-9.89 \pm 5.66 a b$ & $5.72 \pm 3.09 a$ & $12.12 \pm 6.14 a$ \\
\hline \multirow[t]{3}{*}{$\mathrm{Zn}$} & 1 & $20.47 \pm 1.40 b$ & $14.49 \pm 2.05 b$ & $25.26 \pm 8.83 b$ & $25.79 \pm 8.41 b$ & $64.25 \pm 15.42 \mathrm{a}$ \\
\hline & 2 & $33.63 \pm 2.05 a$ & $15.24 \pm 6.57 a b$ & $7.98 \pm 8.87 b$ & $24.36 \pm 5.09 a b$ & $18.60 \pm 4.69 a b$ \\
\hline & 3 & $23.69 \pm 7.19 a$ & $0.50 \pm 10.28 b c$ & $-4.65 \pm 7.65 c$ & $16.54 \pm 5.78 \mathrm{ab}$ & $-3.07 \pm 4.10 \mathrm{bc}$ \\
\hline \multirow[t]{3}{*}{$\mathrm{Cu}$} & 1 & $52.09 \pm 4.36 a$ & $33.95 \pm 2.65 a$ & $-262.96 \pm 75.09 b$ & $-68.93 \pm 100.49 a$ & $32.05 \pm 5.23 a$ \\
\hline & 2 & $40.54 \pm 6.67 a$ & $45.12 \pm 0.00 a$ & $-374.76 \pm 41.55 b$ & $36.41 \pm 0.87 a$ & $37.93 \pm 3.27 a$ \\
\hline & 3 & $44.85 \pm 5.97 a$ & $18.58 \pm 9.01 a$ & $-480.16 \pm 65.28 b$ & $37.28 \pm 0.00 a$ & $31.40 \pm 5.66 a$ \\
\hline \multirow[t]{3}{*}{$\mathrm{Ba}$} & 1 & $16.07 \pm 2.57 a$ & $-53.24 \pm 10.19 b$ & $-51.38 \pm 14.94 b$ & $-11.13 \pm 8.79 a$ & $-14.53 \pm 13.60 a$ \\
\hline & 2 & $7.73 \pm 1.35 a$ & $-58.46 \pm 32.67 \mathrm{~b}$ & $-43.37 \pm 20.89 a b$ & $-12.16 \pm 13.37 a b$ & $-8.44 \pm 10.95 a b$ \\
\hline & 3 & $-34.56 \pm 23.09 a b$ & $-56.08 \pm 32.15 b$ & $-22.80 \pm 11.20 a b$ & $11.20 \pm 9.54 a$ & $5.50 \pm 8.55 a b$ \\
\hline
\end{tabular}


Table 3 Analysis of variance for nutrition resorption efficiencies (F statistics) by the three oak species and five years

\begin{tabular}{lccc}
\hline Element & Plant species & \multicolumn{1}{c}{ Year } & Plant species $\times$ Year \\
\hline $\mathrm{C}$ & 0.10 & $57.52^{*}$ & $3.30^{*}$ \\
$\mathrm{~N}$ & 3.26 & $39.86^{*}$ & 2.67 \\
$\mathrm{P}$ & 1.41 & $369.31^{*}$ & 2.21 \\
$\mathrm{~S}$ & 1.31 & $12.07^{*}$ & 1.03 \\
$\mathrm{~K}$ & 2.62 & 2.47 & 1.32 \\
$\mathrm{Na}$ & 0.07 & $6.69^{*}$ & 0.85 \\
$\mathrm{Ca}$ & 0.58 & $59.11^{*}$ & $4.65^{*}$ \\
$\mathrm{Mg}$ & 0.78 & $3.06^{*}$ & 1.02 \\
$\mathrm{Al}$ & 0.58 & $40.20^{*}$ & 1.97 \\
$\mathrm{Fe}$ & 1.49 & $59.62^{*}$ & $3.60^{*}$ \\
$\mathrm{Mn}$ & 1.16 & 6.91 & 0.65 \\
$\mathrm{Zn}$ & $13.35^{*}$ & $2.66^{*}$ & 1.64 \\
$\mathrm{Cu}$ & 0.54 & $48.95^{*}$ & 1.86 \\
$\mathrm{Ba}$ & 0.90 & 4.08 & 1.05 \\
\hline $\mathrm{Aste}$ & &
\end{tabular}

Asterisks indicate probability level at $P<0.05$

Hierarchical partitioning (HP) analysis was performed to test the combined effects of MAT, MAP, as well as leaf and soil element concentrations on nutrient resorption efficiencies. One-way ANOVA, one-way repeated measures ANOVA, and cluster analyses were performed using SPSS 16.0 (IBM, Chicago, IL, USA). The HP analysis were carried using $\mathrm{R}$ version 3.6.1 ( $\mathrm{R}$ Development Core Team, accessed 2019). The linear regressions and all figures were conducted using SigmaPlot 10.0 (Systat Software, Inc., Richmond, CA, USA).

\section{Results}

Interannual and interspecies variations in nutrient resorption efficiencies

For all elements examined, NuRE generally followed the order of $\mathrm{P}, \mathrm{K}, \mathrm{N}, \mathrm{S}, \mathrm{Mg}, \mathrm{C}, \mathrm{Zn}, \mathrm{Mn}, \mathrm{Na}, \mathrm{Ca}, \mathrm{Ba}, \mathrm{Fe}, \mathrm{Cu}$, and $\mathrm{Al}$ (from high to low) for the three oak species. Generally, the NuRE of $\mathrm{P}, \mathrm{K}, \mathrm{N}, \mathrm{S}, \mathrm{Mg}, \mathrm{C}$, and $\mathrm{Zn}$ was greater than zero, while that of $\mathrm{Mn}, \mathrm{Na}, \mathrm{Ca}, \mathrm{Ba}, \mathrm{Fe}, \mathrm{Cu}$, and $\mathrm{Al}$ was less than zero (Table 2). In the three oak species, with the exception of $\mathrm{Zn}$, the NuREs of other elements did not exhibit significant differences, and over the five years of the study the NuREs of all elements (except for $\mathrm{K}, \mathrm{Mn}$, and $\mathrm{Ba}$ ) showed significant differences (Table 3). Cluster analysis indicated five similar clusters in the three oak species (Fig. 2). Canonical discriminant analysis further indicated that nutrient resorption did not differ between species, but varied significantly between years $(P<0.001)$ (Fig. S1). For all three species, the coefficient of variation $(\mathrm{CV}, \%)$ of elements between the different years generally decreased with higher NuREs (Fig. 3, Table S2).

\section{Effects of climatic and nutritional conditions on plant nutrient resorption}

During the driest year of the study (2014), CRE was significantly enhanced in the oak trees. It was observed that NRE and SRE were generally reduced with higher MAT, while $\mathrm{CaRE}$ and MgRE initially increased and then decreased with MAT (Fig. 4). The CRE and CuRE were typically decreased with higher MAP. Additionally, NRE, PRE, and SRE initially decreased and then increased with MAP, whereas CaRE and MgRE first increased and then decreased with MAP (Fig. 5). The NuREs of most elements were positively correlated with the elemental concentrations of green leaves; however, PRE was negatively correlated with the P concentrations of green leaves (Fig. S2).

Hierarchical partitioning analysis indicated temporal variations in NuRE over the years under study, from $18.13 \%$ KRE to $96.04 \%$ PRE in the three oak species (Table S3). The NRE was strongly associated with MAT and leaf N, CuRE with MAP in the three species, PRE with MAT and leaf P, MgRE with MAT in Q. aliena var. acuteserrata and Q. glandulifera, and $\mathrm{CaRE}, \mathrm{MnRE}$, and BaRE with MAT and leaf elements
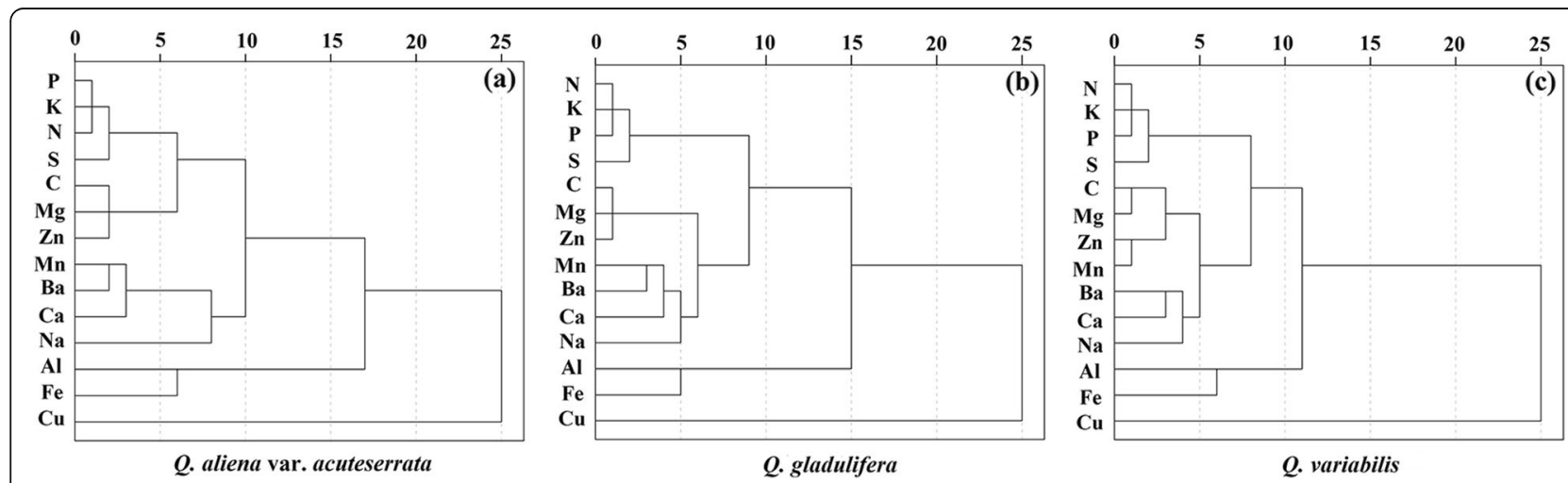

Fig. 2 Element classification by nutrient resorption efficiency and species using cluster analysis: Q. aliena var. acuteserrata (a), Q. glandulifera (b), and Q. variabilis (c) 


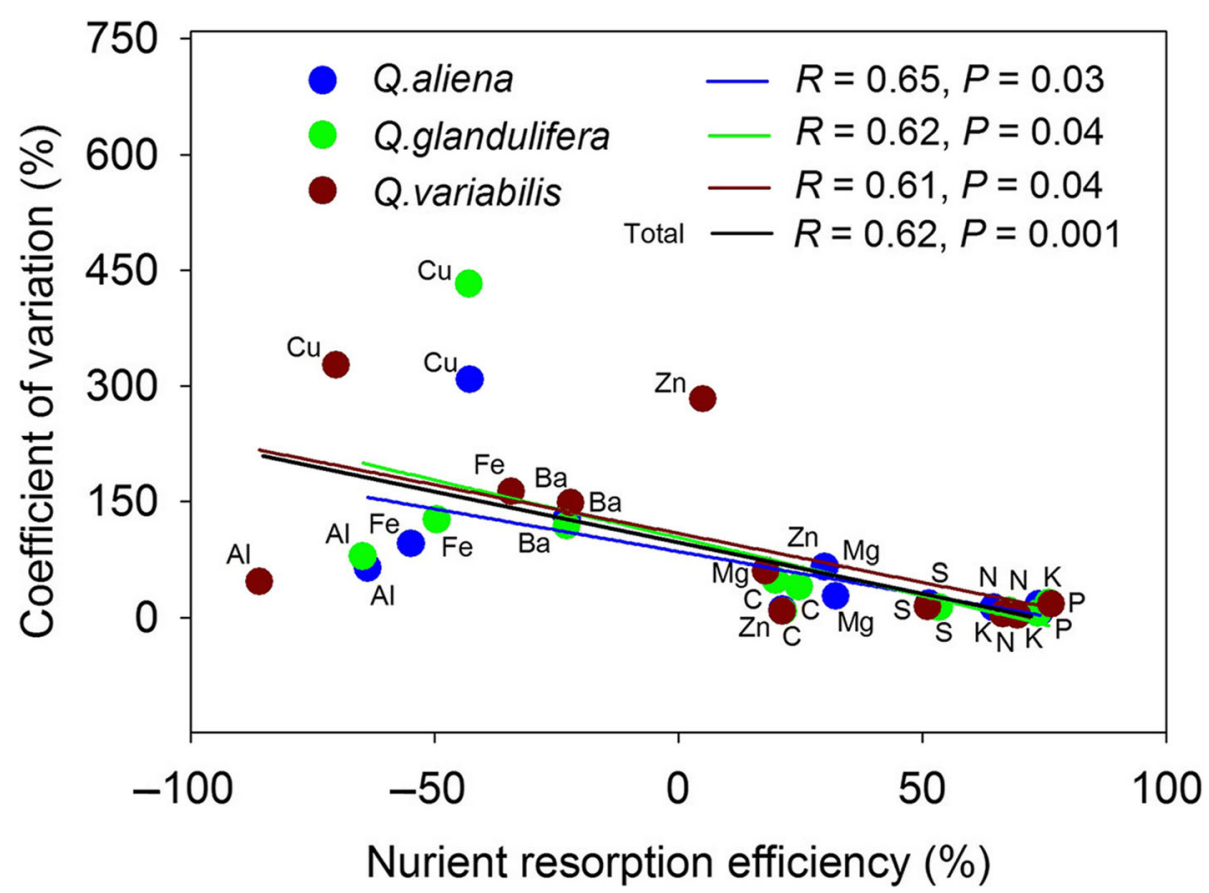

Fig. 3 Relationships between mean nutrient resorption efficiencies and coefficient of variations (CV). Ca, Na, and Mn are showed in Table S2

in Q. glandulifera and Q. variabilis. The NuRE of the remaining elements was mostly related to leaf element concentrations, except for $\mathrm{K}, \mathrm{Na}$, and $\mathrm{Cu}$. Soil elements did not influence NuRE, except for CRE in $Q$. glandulifera and ZnRE in Q. variabilis (Table S3).

\section{Discussion}

\section{Analogous response of interspecies NuREs to interannual} climate variability

In contrast to deciduous plants on a global scale (Vergutz et al. 2012), the three oak species under study demonstrated higher $\mathrm{N}, \mathrm{P}$, and $\mathrm{K}$ resorption efficiencies, but lower $\mathrm{C}$ and $\mathrm{Mg}$ resorption efficiencies. The NuRE of $\mathrm{N}$ and $\mathrm{P}$ in this study was higher than that of deciduous plants in a subtropical karst region (Liu et al. 2014), and higher than that of $Q$. variabilis across China (Sun et al. 2015). These results signified that plants may have more $\mathrm{N}$ and $\mathrm{P}$ demand for growth in this region. This may have been because the plants grew at high altitudes where due to low temperatures, they required higher levels of nutrient resorption to store nutrients for the following growing season. This was demonstrated by Du et al. (2017), who found that the resorption of N, P, and S (at least in Q. variabilis) was the greatest at high altitudes. Moreover, PRE in the three oaks was greater than NRE (except in 2018). This was in alignment with the research of Chai et al. (2015) and Du et al. (2017), who revealed that in the same or neighboring regions, the growth of oaks was commonly restrained by $\mathrm{P}$ in contrast to $\mathrm{N}$.
As a conservation mechanism, nutrient resorption plays a key role in balancing plant nutrient demands and acquisition (Killingbeck 2004; Brant and Chen 2015). Our results revealed that NuRE varied significantly among the different years but did not differ between species. Interestingly, the three oak species displayed analogous NuRE responses to interannual climate variability, particularly for $\mathrm{C}, \mathrm{N}, \mathrm{P}, \mathrm{S}, \mathrm{Mg}, \mathrm{Fe}$, $\mathrm{Mn}$, and $\mathrm{Cu}$ (Table 2), and cluster analysis also indicated five similar clusters in the three oak species (Fig. 2). The similarity in NuRE between different plants indicated that the same plant types (only deciduous plants were investigated in the study) growing in the same region might have parallel or convergent mechanisms in terms of nutrient conservation (Yeaman et al. 2016). This aligned well with a study by Bahamonde et al. (2019), who found that the NuRE did not vary between Nothofagus pumilio and $N$. antarctica at the sites they investigated. Similar results were reported following a five year manipulative field study by Prieto and Querejeta (2020), and demonstrated by Lü et al. (2013), who found that with $\mathrm{N}$ inputs, plants exhibited a convergent response in the resportion of $\mathrm{N}$ and $\mathrm{P}$. These results indicated that plants growing under the same conditions, or occupying the same niche, may experience analogous limitations for nutrient absorption and conservation processes. Thus, our findings may have important implications for the study of localized plant adaptations and evolution. 


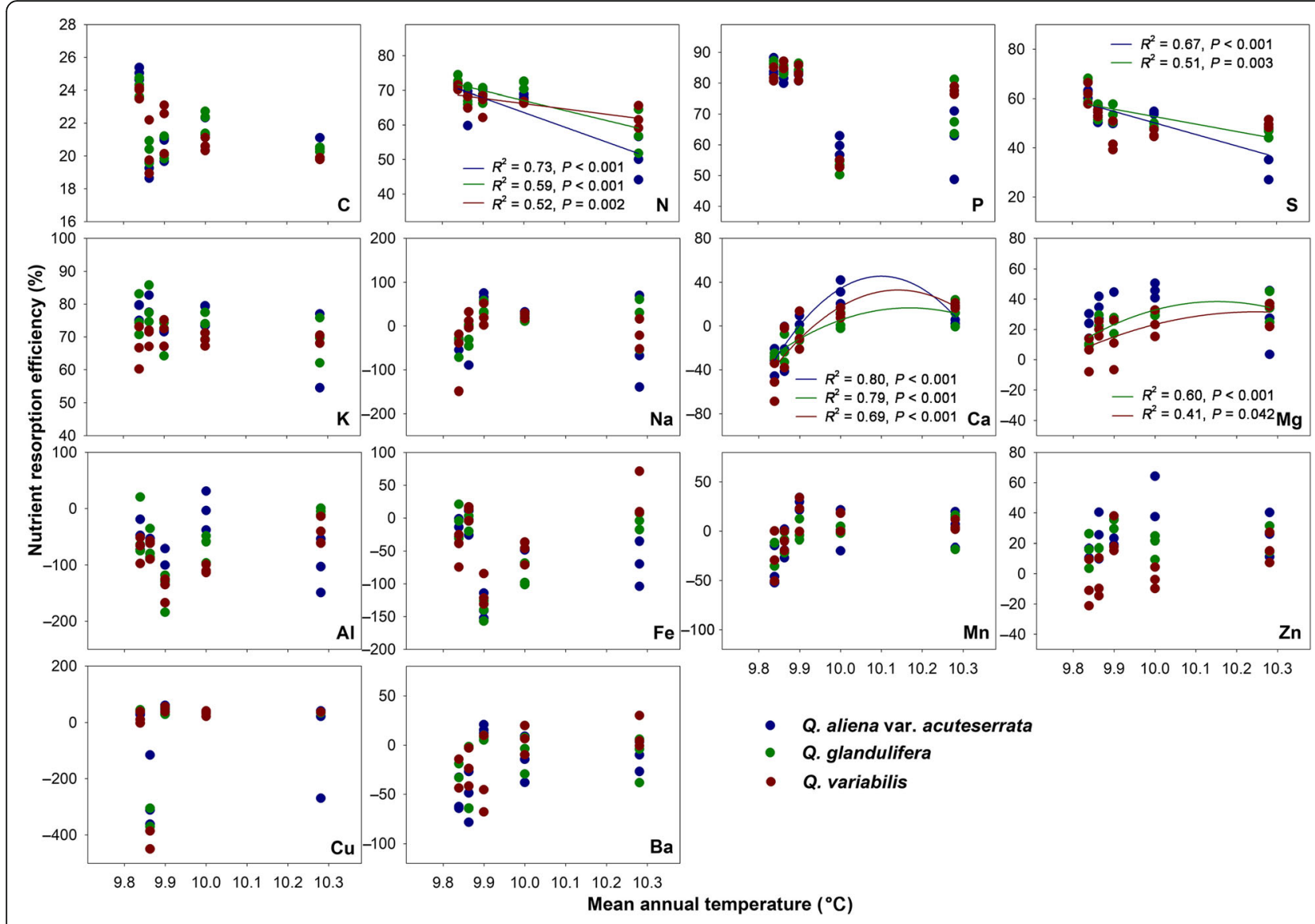

Fig. 4 Relationships between element resorption efficiencies and mean annual temperature

In addition, our results showed that the NuRE of $\mathrm{P}, \mathrm{K}$, $\mathrm{N}, \mathrm{S}, \mathrm{Mg}, \mathrm{C}$, and $\mathrm{Zn}$ was greater than zero, while that of $\mathrm{Mn}, \mathrm{Na}, \mathrm{Ca}, \mathrm{Ba}, \mathrm{Fe}, \mathrm{Cu}$, and $\mathrm{Al}$ was less than zero in the three oak species (Table 2), which was demonstrated by the study of Du et al. (2017) for Q. variabilis. Macroelements (P, K, N, S, Mg, C, and Zn) that are constituents of amino acids, proteins, nucleic acids, and enzymes (Marschner and Marschner 2012) are essential for new growth, and therefore had a high resorption efficiency (except for Ca) (Liu et al. 2014; Du et al. 2017). Microelements and trace elements $\mathrm{Mn}, \mathrm{Na}, \mathrm{Ca}, \mathrm{Ba}, \mathrm{Fe}, \mathrm{Cu}$, and $\mathrm{Al}$ ) are closely related to enzymes, cell structure and detoxification. The negative resorption efficiencies of these elements have also been reported previously (Killingbeck 1993; Liu et al. 2014; Du et al. 2017). This is likely due to these nutrients being freely loaded into xylem but highly restricted in phloem (Bukovac and Wittwer 1957; Hill 1980), which limits their inputs into perennial tissues, and therefore had a low even negative resorption efficiency. As expected, seasonal variations in the elements of $Q$. variabilis of the same region also demonstrated low nutrients for microelements and trace elements and high nutrients for macroelements at the onset of the growing season (Du et al. 2021). These findings indicated that the oak species engaged in resorption trade-offs as the end of the growing season approached, which may affect plant regrowth. Furthermore, we found that the elemental CVs between different years generally decreased with higher NuREs in all three oak species (Fig. 3) as supported by the study of Karimi and Folt (2006). This was because high elemental concentrations with low variability benefitted plants by maintaining their homeostasis (Han et al. 2011).

\section{Effects of interannual climate, and leaf and soil nutrient status on NuRE}

Significant fluctuations in nutrient resorption due to interannual variabilities in temperature and precipitation were reported in two prior studies (May and Killingbeck 1992; Killingbeck 1993). Of the fourteen elements examined the NuRE of $\mathrm{C}, \mathrm{N}, \mathrm{P}, \mathrm{S}, \mathrm{Ca}$, and $\mathrm{Mg}$ was closely associated with MAT and MAP (Figs. 4 and 5). The results suggested that these elements were more sensitive to interannual climate variability compared to others, which due to their importance translated to limitations in photosynthesis and growth in plants (Elser et al. 2007; Marschner and 


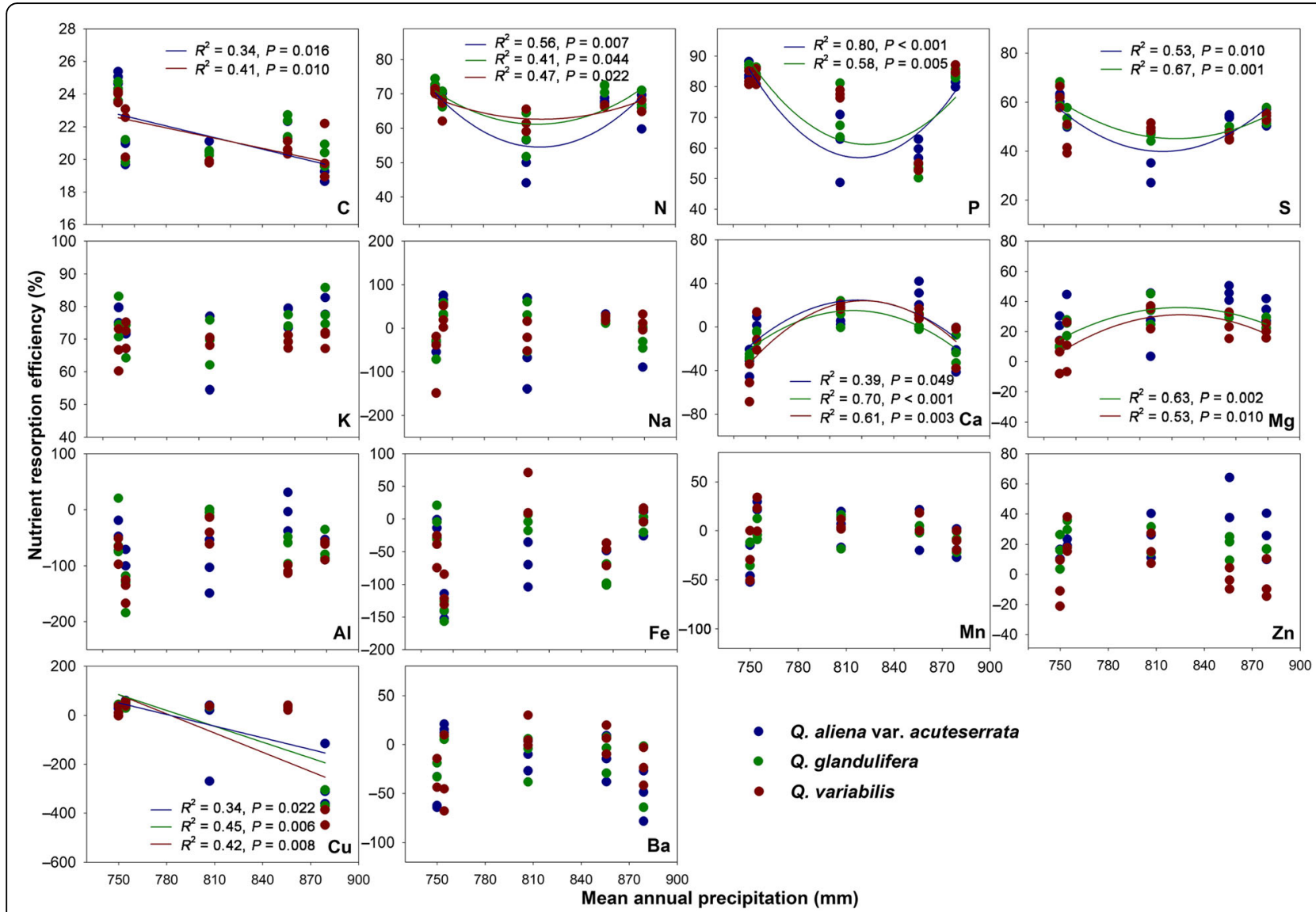

Fig. 5 Relationships between element resorption efficiencies and mean annual precipitation

Marschner 2012). This finding signified that the responses of resorption to climatic variability were contingent on element type (Vergutz et al. 2012; Sun et al. 2015; Du et al. 2017), where some elements that are directly related to growth (such as nucleic acid-proteins and photosynthetic elements) may be more sensitive to climate change.

There was negative relationship between NRE and temperature across all species (Fig. 4), which was demonstrated in numerous previous studies (Yuan and Chen 2009; Sun et al. 2015; Prieto and Querejeta 2020). This was primarily because colder temperatures not only inhibited the metabolic activity of plants, but also restricted nutrient release and root $\mathrm{N}$ uptake. Consequently, plants need to extract additional $\mathrm{N}$ to enhance metabolic activity and growth rates, while reducing their dependence on available soil nutrients. This result also uncovered the interesting finding that temperature had a consistent influence on NRE regardless of spatial or temporal scales. However, precipitation had more complex influence on nutrient resorption. For instance, NRE and PRE initially decreased and then increased with MAP (Fig. 5). Comparatively, Yuan and Chen (2009) found that $\mathrm{P}$ resorption increased with higher precipitation, while Vergutz et al. (2012) reported that N and P resorption decreased with precipitation on a global scale. Moreover, Du et al. (2017) found that N and P resorption was enhanced with precipitation along an altitude gradient in the same area. Our study indicated that excessive or low precipitation may have restricted the growth of plants, which resulted in high $\mathrm{N}$ and $\mathrm{P}$ resorption. These results revealed that precipitation may play a predominant role in the determination of nutrient demands and plant growth in different oak forests.

During the driest year of the study (2014) CRE was significantly enhanced in the oak trees (Table 2), which suggested that plants may store additional energy for reproduction under drought conditions (Vergutz et al. 2012). Correspondingly, the concentrations of $\mathrm{C}$ in the litter of the forest floor were reduced (Fig. S3), as was demonstrated by Sardans et al. (2008). This might influence future litter quality and decomposition, and even ecosystem $\mathrm{C}$ cycling. Based on the predicted changes in local temperature and precipitation $\left(0.9{ }^{\circ} \mathrm{C}\right.$ higher annual mean temperature and $6.4 \mathrm{~mm}$ lower total precipitation over the next twenty years) (Zhao et al. 2012), the 
resorption efficiency of $\mathrm{C}, \mathrm{N}$, and $\mathrm{P}$ will likely (to some extent) decrease over the next twenty years (Table S4), as demonstrated by Prieto and Querejeta (2020). This decrease likely reduced nutrient demands and plant growth and may have some influence on litter quality and decomposition (Prescott 2010; Prieto et al. 2019).

NuRE was also associated with the elemental concentrations of green leaves. Surprisingly, there were positive relationships between the concentrations of leaf element and NuREs (except for P) (Fig. S2). Our results were different from previous studies, where the high nutrient contents of green leaves typically led to low nutrient resorption (Kobe et al. 2005; Ratnam et al. 2008; Vergutz et al. 2012), or there was no significant relationship between them (Chapin and Moilanen 1991; Aerts 1996). For our study, the relationships between the elemental concentrations of green leaves and climatic factors were also analyzed, which were consistent with the relationships between NuRE and climatic factors. This revealed that both the elemental concentrations of green leaves and the resorption of nutrients were impacted by climatic factors, which may form coupling relationships. When plants possessed high nutrient concentrations during the growing season, increased nutrient resorption was likely to occur at the end of the growing season to maintain a source-sink balance (Killingbeck 2004). Furthermore, we found that soil had no influence on NuRE during the years under study (Table S3), which agreed with the findings of Aerts (1996) and Aerts and Chapin (1999). This was likely caused by the low fluctuation of available soil nutrients between years and low sensitivity to changes in the soil due to the long-term adaptation to the local environment.

\section{Conclusions}

Our study described a comprehensive representation relating to the interannual patterns of nutrient resorption of multiple elements in three oak species. Our conclusions were that (1) different plants growing in the same region may have analogous nutrient conservation strategies in response to interannual climate change; (2) at the conclusion of the growing season deciduous plants may engage a tradeoff mechanism to rebalance nutrients for regrowth; (3) interannual climate variations strongly impacted plant nutrient resorption, particularly, $\mathrm{C}, \mathrm{N}, \mathrm{P}, \mathrm{S}, \mathrm{Ca}$, and $\mathrm{Mg}$, which play important roles in adapting to interannual climate variabilities and reproduction. Our findings have clear implications for understanding localized plant adaptation strategies and biogeochemical cycling processes under global climate change.

\section{Abbreviations}

NuRE: Nutrient resorption efficiency; C: Carbon; N: Nitrogen; P: Phosphorus; S: Sulfur; K: Potassium; Na: Sodium; Ca: Calcium; Mg: Magnesium; Al: Aluminum; Fe: Iron; Mn: Manganese; Zn: Zinc; Cu: Copper; Ba: Barium; CRE: Carbon resorption efficiency; NRE: Nitrogen resorption efficiency; PRE: Phosphorus resorption efficiency; SRE: Sulfur resorption efficiency; KRE: Potassium resorption efficiency; NaRE: Sodium resorption efficiency; CaRE: Calcium resorption efficiency; MgRE: Magnesium resorption efficiency; AIRE: Aluminum resorption efficiency; FeRE: Iron resorption efficiency; MnRE: Manganese resorption efficiency; ZnRE: Zinc resorption efficiency; CURE: Copper resorption efficiency; BaRE: Barium resorption efficiency; MAT: Mean annual temperature; MAP: Mean annual precipitation; CV: Coefficient variation

\section{Supplementary Information}

The online version contains supplementary material available at https://doi. org/10.1186/s40663-021-00350-8.

\section{Additional file 1}

\section{Acknowledgements}

We thank Xiaojing Liu for fieldwork assistance and Rongzhou Man for helpful comments.

\section{Authors' contributions}

$\mathrm{CL}$ designed the study; SL provided climatic data; $\mathrm{BD}$, and $\mathrm{HJ}$ conducted field studies and chemical analyses; BD, SY, and HK wrote the manuscript. All authors approve the paper.

\section{Funding}

This work was supported by the National Key Technology Research and Development Program of China (2017YFC0505501, 2016YFD0600206, and 2013BAD11B01), the National Natural Science Foundation of China (NSFC 31270640 and 31770746), and the China Postdoctoral Science Foundation (20Z102060010)

\section{Availability of data and materials}

The datasets used and/or analyzed during the current study are available from the corresponding author on reasonable request.

\section{Declarations}

Ethics approval and consent to participate

This research is not considered to involve ethical problems.

Consent for publication

Not applicable.

\section{Competing interests}

There are no competing interests.

\section{Author details}

${ }^{1}$ School of Agriculture and Biology, Shanghai Jiao Tong University, 200240 Shanghai, China. ${ }^{2}$ Key Laboratory of Forest Ecology and Environment, China's State Forestry Administration, Research Institute of Forest Ecology, Environment and Protection, Chinese Academy of Forestry, 100091 Beijing, China. ${ }^{3}$ Shanghai Urban Forest Ecosystem Research Station, State Forestry Administration, 200240 Shanghai, China. ${ }^{4}$ Shanghai Yangtze River Delta Eco-environmental Change and Management Observation and Research Station, Ministry of Science and Technology, 200240 Shanghai, China.

${ }^{5}$ Shanghai Urban Forest Ecosystem Research Station, State Forestry

Administration, 200240 Shanghai, China.

Received: 22 June 2021 Accepted: 11 October 2021

Published online: 15 November 2021

\section{References}

Aerts R (1996) Nutrient resorption from senescing leaves of perennials: are there general patterns? J Ecol 84:597-608 
Aerts R, Chapin FS (1999) The mineral nutrition of wild plants revisited: a reevaluation of processes and patterns. Adv Ecol Res 30:1-67

Aldrich PR, Cavender-Bares J (2011) Quercus, wild crop relatives: genomic and breeding resources. Springer, Berlin Heidelberg

Aspinwall MJ, Drake JE, Campany C, Vårhammar A, Ghannoum O, Tissue DT, Reich PB, Tjoelker MG (2016) Convergent acclimation of leaf photosynthesis and respiration to prevailing ambient temperatures under current and warmer climates in Eucalyptus tereticornis. New Phytol 212:354-367

Attiwill PM, Adams MA (1993) Nutrient cycling in forests. New Phytol 124:561-582

Bahamonde HA, Fernández V, Gyenge J, Mattenet F, Peri PL (2019) Essential nutrient and trace element foliar resorption of two co-existing Nothofagus species grown under different environmental conditions in southern Patagonia. Front Plant Sci 10:1542. https://doi.org/10.3389/fpls.2019.01542

Bauters M, Verbeeck H, Demol M, Bruneel S, Taveirne C, Van der Heyden D, Cizungu L, Boeckx P (2017) Parallel functional and stoichiometric trait shifts in South American and African forest communities with elevation. Biogeosciences 14:5313-5321

Brant AN, Chen HY (2015) Patterns and mechanisms of nutrient resorption in plants. Crit Rev Plant Sci 34:471-486

Bukovac MJ, Wittwer SH (1957) Absorption and mobility of foliar applied nutrients. Plant Physiol 32:428-435

Chai Y, Zhang X, Yue M, Liu X, Li Q, Shang H, Meng Q, Zhang R (2015) Leaf traits suggest different ecological strategies for two Quercus species along an altitudinal gradient in the Qinling Mountains. J Forest Res 20:501-513

Chapin FS, Moilanen L (1991) Nutritional controls over nitrogen and phosphorus resorption from Alaskan birch leaves. Ecology 72:709-715

Cronan C (2017) Ecosystem biogeochemistry: element cycling in the forest landscape. Springer, Cham

Drenovsky RE, Pietrasiak N, Short TH (2019) Global temporal patterns in plant nutrient resorption plasticity. Global Ecol Biogeogr 28:728-743

Du B, Ji H, Peng C, Liu X, Liu C (2017) Altitudinal patterns of leaf stoichiometry and nutrient resorption in Quercus variabilis in the Baotianman Mountains, China. Plant Soil 413:193-202

Du B, Zheng J, Ji H, Zhu Y, Yuan J, Wen J, Kang H, Liu C (2021) Stable carbon isotope used to estimate water use efficiency can effectively indicate seasonal variation in leaf stoichiometry. Ecol Indic 121:107250

Elser JJ, Bracken ME, Cleland EE, Gruner DS, Harpole WS, Hillebrand H, Ngai JT, Seabloom EW, Shurin JB, Smith JE (2007) Global analysis of nitrogen and phosphorus limitation of primary producers in freshwater, marine and terrestrial ecosystems. Ecol Lett 10:1135-1142

Estiarte M, Peñuelas J (2015) Alteration of the phenology of leaf senescence and fall in winter deciduous species by climate change: effects on nutrient proficiency. Glob Chang Biol 21:1005-1017

Fujita Y, Venterink HO, van Bodegom PM, Douma JC, Heil GW, Holzel N, Jablonska E, Kotowski W, Okruszko T, Pawlikowski P, de Ruiter PC, Wassen MJ (2014) Low investment in sexual reproduction threatens plants adapted to phosphorus limitation. Nature 505:82-86

Gerdol R, lacumin P, Brancaleoni L (2019) Differential effects of soil chemistry on the foliar resorption of nitrogen and phosphorus across altitudinal gradients. Funct Ecol 33:1351-1361

Han WX, Fang JY, Reich PB, lan Woodward F, Wang ZH (2011) Biogeography and variability of eleven mineral elements in plant leaves across gradients of climate, soil and plant functional type in China. Ecol Lett 14:788-796

Hill J (1980) The remobilization of nutrients from leaves. J Plant Nutr 2:407-444

Huang G, Su YG, Mu XH, Li Y (2018) Foliar nutrient resorption responses of three life-form plants to water and nitrogen additions in a temperate desert. Plant Soil 424:479-489

IPCC (2014) Pachauri RK, Meyer LA (eds) Climate change 2014: synthesis report. Contribution of working groups I, II and III to the fifth assessment report of the Intergovernmental Panel on Climate Change. Cambridge University Press, Cambridge

Jump AS, Peñuelas J (2005) Running to stand still: adaptation and the response of plants to rapid climate change. Ecol Lett 8:1010-1020

Karimi R, Folt CL (2006) Beyond macronutrients: element variability and multielement stoichiometry in freshwater invertebrates. Ecol Lett 9:1273-1283

Killingbeck KT (1993) Inefficient nitrogen resorption in genets of the actinorhizal nitrogen fixing shrub Comptonia peregrina: physiological ineptitude or evolutionary tradeoff? Oecologia 94:542-549

Killingbeck KT (2004) Nutrient resorption. In: Noodén LD (ed) Plant cell death processes. Academic Press, Cambridge
Kobe RK, Lepczyk CA, lyer M (2005) Resorption efficiency decreases with increasing green leaf nutrients in a global data set. Ecology 86:2780-2792

Liu CC, Liu YG, Guo K, Wang SJ, Yang Y (2014) Concentrations and resorption patterns of 13 nutrients in different plant functional types in the karst region of south-western China. Ann Bot 113:873-885

Liu Y, Liu S, Wan S, Wang J, Wang H, Liu K (2017) Effects of experimental throughfall reduction and soil warming on fine root biomass and its decomposition in a warm temperate oak forest. Sci Total Environ 574:14481455

Lobo-do-Vale R, Kurz BC, Caldeira MC, Chaves MM, Pereira JS (2019) Drought reduces tree growing season length but increases nitrogen resorption efficiency in a Mediterranean ecosystem. Biogeosciences 16:1265-1279

Lü XT, Hou SL, Reed S, Yin JX, Hu YY, Wei HW, Zhang ZW, Yang GJ, Liu ZY, Han XG (2021) Nitrogen enrichment reduces nitrogen and phosphorus resorption through changes to species resorption and plant community composition. Ecosystems 24:602-612

Lü XT, Reed S, Yu Q, He NP, Wang ZW, Han XG (2013) Convergent responses of nitrogen and phosphorus resorption to nitrogen inputs in a semiarid grassland. Glob Chang Biol 19:2775-2784

Marschner H, Marschner P (2012) Marschner's mineral nutrition of higher plants. Academic Press, California

May JD, Killingbeck KT (1992) Effects of preventing nutrient resorption on plant fitness and foliar nutrient dynamics. Ecology 73:1868-1878

Pallardy S (2010) Physiology of woody plants. Academic Press, California

Prescott CE (2010) Litter decomposition: what controls it and how can we alter it to sequester more carbon in forest soils? Biogeochemistry 101:133-149

Prieto I, Almagro M, Bastida F, Querejeta JI (2019) Altered leaf litter quality exacerbates the negative impact of climate change on decomposition. J Ecol 10:2364-2382

Prieto I, Querejeta JI (2020) Simulated climate change decreases nutrient resorption from senescing leaves. Glob Chang Biol 26:1795-1807

Ratnam J, Sankaran M, Hanan NP, Grant RC, Zambatis N (2008) Nutrient resorption patterns of plant functional groups in a tropical savanna: variation and functional significance. Oecologia 157:141-151

Reed SC, Townsend AR, Davidson EA, Cleveland CC (2012) Stoichiometric patterns in foliar nutrient resorption across multiple scales. New Phytol 196: 173-180

Sardans J, Penuelas J, Estiarte M, Prieto P (2008) Warming and drought alter C and $\mathrm{N}$ concentration, allocation and accumulation in a Mediterranean shrubland. Glob Chang Biol 14:2304-2316

Sun X, Kang H, Du H, Hu H, Zhou J, Hou J, Zhou X, Liu C (2012) Stoichiometric traits of oriental oak (Quercus variabilis) acorns and their variations in relation to environmental variables across temperate to subtropical China. Ecol Res 27:765-773

Sun X, Kang H, Chen HY, Berg B, Bartels SF, Liu C (2015) Biogeographic patterns of nutrient resorption from Quercus variabilis Blume leaves across China. Plant Biol 18:505-513

Suseela V, Tharayil N, Xing B, Dukes JS (2015) Warming and drought differentially influence the production and resorption of elemental and metabolic nitrogen pools in Quercus rubra. Glob Chang Biol 21:4177-4195

Tong R, Zhou B, Jiang L, Ge X, Cao Y (2021) Spatial patterns of leaf carbon, nitrogen, and phosphorus stoichiometry and nutrient resorption in Chinese fir across subtropical China. Catena 201:105221

Vergutz L, Manzoni S, Porporato A, Novais RF, Jackson RB (2012) Global resorption efficiencies and concentrations of carbon and nutrients in leaves of terrestrial plants. Ecol Monogr 82:205-220

Wright IJ, Westoby M (2003) Nutrient concentration, resorption and lifespan: leaf traits of Australian sclerophyll species. Funct Ecol 17:10-19

Xu JW, Lin G, Liu B, Mao R (2020) Linking leaf nutrient resorption and litter decomposition to plant mycorrhizal associations in boreal peatlands. Plant Soil 448:413-424

Xu M, Zhong Z, Sun Z, Han X, Ren C, Yang G (2020) Soil available phosphorus and moisture drive nutrient resorption patterns in plantations on the Loess Plateau. Forest Ecol Manag 461:117910

Yan Z, Li P, Chen Y, Han W, Fang J (2016) Nutrient allocation strategies of woody plants: an approach from the scaling of nitrogen and phosphorus between twig stems and leaves. Sci Rep 6:20099

Yeaman S, Hodgins KA, Lotterhos KE, Suren H, Nadeau S, Degner JC, Nurkowski KA, Smets P, Wang T, Gray LK, Liepe KJ, Hamann A, Holliday JA, Whitlock MC, Rieseberg LH, Aitken SN (2016) Convergent local adaptation to climate in distantly related conifers. Science 353:1431-1433 
Yuan Z, Chen HY (2009) Global-scale patterns of nutrient resorption associated with latitude, temperature and precipitation. Global Ecol Biogeogr 18:11-18

Zhao G, Li T, Wang J, Cao S, Wang J (2012) Predition reseach of climate change trends in Henan Provience in the future 30 years. Henan Water Resour South-to-North Water Diversion 2:8-10 (in Chinese)

Zhao Q, Guo J, Shu M, Wang P, Hu S (2020) Impacts of drought and nitrogen enrichment on leaf nutrient resorption and root nutrient allocation in four Tibetan plant species. Sci Total Environ 723:138106

Zheng J, She W, Zhang Y, Bai Y, Qin S, Wu B (2018) Nitrogen enrichment alters nutrient resorption and exacerbates phosphorus limitation in the desert shrub Artemisia ordosica. Ecol Evol 8:9998-10007

\section{Submit your manuscript to a SpringerOpen ${ }^{\odot}$} journal and benefit from:

- Convenient online submission

- Rigorous peer review

- Open access: articles freely available online

- High visibility within the field

- Retaining the copyright to your article

Submit your next manuscript at $\boldsymbol{\nabla}$ springeropen.com 